Plevachuk Lubov, Grygus Igor, Małolepszy Eligiusz. Development of physical culture and sports in Krements and Volyn between the military period during the activity of Julian Kozlowski, professor of Kremenets Lyceum. Pedagogy and Psychology of Sport. 2020;6(2):212218. elSSN 2450-6605. DOI http://dx.doi.org/10.12775/PPS.2020.06.02.021

https://apcz.umk.pl/czasopisma/index.php/PPS/article/view/PPS.2020.06.02.021

https://zenodo.org/record/4026210

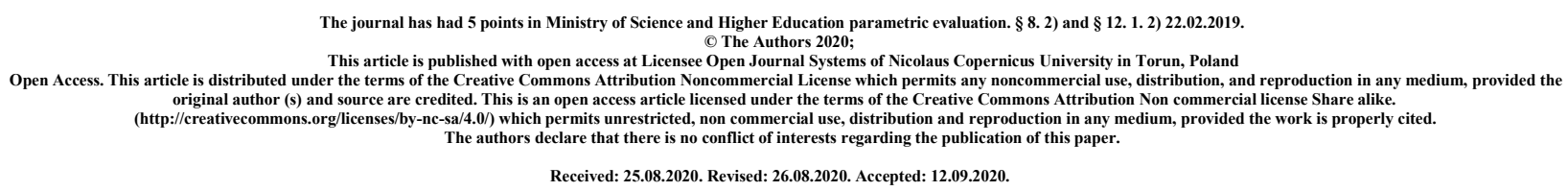

Received: 25.08.2020. Revised: 26.08.2020. Accepted: 12.09.2020.

\title{
DEVELOPMENT OF PHYSICAL CULTURE AND SPORTS IN KREMENTS AND VOLYN BETWEEN THE MILITARY PERIOD DURING THE ACTIVITY OF JULIAN KOZLOWSKI, PROFESSOR OF KREMENETS LYCEUM
}

\author{
Lubov Plevachuk $^{1}$, Igor Grygus ${ }^{2,3}$, Eligiusz Małolepszy ${ }^{3}$
}

${ }^{1}$ Taras Shevchenko Kremenets Regional Humanitarian and Pedagogical Academy, Kremenets, Ukraine

${ }^{2}$ National university of water and environmental engineering, Rivne, Ukraine

${ }^{3}$ Jan Długosz University, Czestochowa, Poland

Lubov Plevachuk https://orcid.org/0000-0002-9609-7542

Igor Grygus https://orcid.org/0000-0003-2856-8514

Eligiusz Małolepszy https://orcid.org/0000-0003-2373-6048

Summary: This article describes Professor Julian Kozlowski's activity at Kremenets Lyceum. Being an excellent specialist, he raised physical culture and sports to a new level, which made Kremenets Lyceum one of the best sports centers in Volyn.

Here it is shown the importance of innovations, including the Dalton system, implemented at physical education classes in Kremenets Lyceum.

Due to Julian Kozlowski"s persistence, there were introduced mass sports tests for Ski Distinction and for State Sports Honors.

Thanks to his initiative, ski jumping, swimming pool on the river Ikva, stadium, tennis courts were built here. He also participated in the construction of gliding sport school on Sokolyna Mountain near Kremenets.

Professor Kozlowski gave lectures and courses to popularize physical culture and sports. He initiated various competitions and sports events.

Julian Kozlowski was a great patriot of Poland. 
Key words: Dalton system, ski jumping, sports competitions, sports honors, sports organizations, specialist training courses.

\section{Formulation and relevance of the problem}

Awakening interest in physical culture and sports in Krements dates back to the beginning of the twentieth century. The number of young people and adults being interested in various kinds of sports is increasing.

Kremenets Lyceum occupies an important place in the development of physical culture and sports owing to the great specialists working here, including Professor Julian Kozlowski. His significant contribution to the development of various sports, along with the building of sports facilities raised Kremenets Lyceum to a new level.

Analysis of recent research and publications. The analysis of literary sources showed that the development of physical education and sports in Krements was studied out by such authors as O. Levandovska, S. Grudnyak, A. Voynarowski, M. Pryshchepa, L. Zhyvek, V. Nosowski and others.

However, Professor Yulian Kozlowski's life, his work at Kremenets Lyceum and his great contribution to the development of physical culture and sports not only in Krements but also in Volyn, have not been fully covered yet.

The main material. According to Jozef Pilsudski's order (on 27 of May 1920) Kremenets Lyceum resumed its activity and became the center of education and development of physical culture and sports in Volyn [10].

Among the great specialists working at Kremenets Lyceum there were Jan Targonski, Galina Falkowska, Alexander Berger, Ludwik Gronowski, Julian Kozlowski. Alongside Julian Kozlowski was a great enthusiast and promoter of sports not only in the lyceum, but also among the residents of the city, personally taking part in organization and refereeing competitions of different ranks in many sports. He was also an active contributor to the local press where his articles were published.

Julian Kozlowski was born on January 6, 1898 in Warsaw, where he spent his childhood until 1905. Then he with his parents went to Estonia, where tsar's authority sent his father because of taking part in patriotic activity. In 1914 Kozlowski"s family moved to Petrograd, where Julian finished Polish Real School (Szkoła Realna Polskiej Macierzy Szkolnej).

Before coming to Kremenets his life was not easy. Since growing up in a patriotic family Julian, being a student and despite the parents' ban, made attempts to join the Polish Legions of Józef Pilsudski in1914, when the First World War began.

In 1915 he was engaged in scout activity, organizing Polish scout units.

From 1918 to 1921 Julian Kozlowski served in many Polish military formations and took part in the battles against the Bolsheviks. Being twice imprisoned by Bolsheviks he avoided punishment and even escaped from captivity several times [16].

After Poland gained independence, in 1921Julian entered Warsaw Polytechnic but due to his difficult financial situation he was forced to interrupt his studies.

In 1922 he was the head of school in New Yard town, and then in 1925 he worked as a "teacher of physical exercises" at Teachers' Seminary in Bialystok. In the same year, he entered the Institute of Physical Education in Warsaw and got a certificate of an instructor in 1927. Julian Kozlowski received his full teacher education in 1930 after graduating from additional pedagogical courses [16].

From 1927 to 1939 Professor Julian Kozlowski worked as a teacher of physical education at Kremenets Lyceum [14]. 
Physical culture in the educational system of this institution took a proper place. Athletics, sports games, skiing, ice skating, hockey, tennis, and shooting were the most popular kinds of sports. There were good sports facilities. Two gymnasiums, two tennis courts, a track-and-field athletic stadium, 4 volleyball courts and one basketball court, as well as a place where hockey fans could practice in winter contributed to the development of many sports [10].

At that time, a Dalton training system was objectified at Kremenets Lyceum. Professor Kozlowski had his own vision of applying this system to physical education. In 1931 he initiated a meticulous medical examination of lyceum students. There were also determined the level of their physical condition and the level of physical training. According to these data, Julian Kozlowski divided the students into 4 groups, that's why the under-trained students received moderate tasks and they stopped feeling embarrassed among physically stronger students. The best athletes who participated in various competitions were in the first group. The number of members in the group was not constant though, those students who increased their athletic level moved into the higher group, and vice versa. Successful studying was a prerequisite for being in the first group, the students who received poor grades, despite being strong athletes, could be sent into the second group. It encouraged the students not only to be in a great physical fit, but to study well [2].

As a teacher of Kremenets Lyceum, Julian Kozlowski took part actively not only in the development of physical culture, but also in a social life of the local community.

Professor Kozlowski headed the Physical Education Department of State Defense and Physical Education Section of the Association of Public Organizations, which was established in Kremenets on the 29 of December, 1931.

Julian Kozlowski was also a member of Kremenets Sports Club, and in 1932 at a meeting he was elected as its board member. To attract young people to the sport activity, to strengthen the work of sports sections, to prepare athletes for participation in competitions were the main tasks of the club [17].

Professor Kozlowski's activity was successful and well-regarded, and in the late 1930s he was elected as a chairman of Kremenets Sports Club. He worked successfully occupying this post until 1939 [15].

Julian Kozlowski made a great contribution to the development of winter sports and winter tourism. He organized various ski racing and ski jumping competitions.

One of Professor Kozlowski's initiatives was to create a winter sports center in Kremenets. There were such sports as skiing, sledging, ice skating and hockey. He also believed that there should be a Ski Section, registered by the Polish Skiers' Union, which would pay attention to the development of skiing in the territory of Kremenets district [13].

In 1925 here, in Kremenets, the award for skiing was established. This award was very prestigious and served to popularize sports with the public [5].

The State Sports Distinction for the people who showed positive results in physical fitness was established by a resolution of the Council of Ministers on June 27, 1930. The main purpose of the honors was to improve the level of physical training of population and to maintain good sportsmanship for a long time [2].

Professor Kozlowski was an organizer of sports tests for lyceum students and citizens of the city so that they could obtain mentioned sports awards. It was very prestigious to receive such honors, and it was a necessary condition for them to take part in competitions [2].

Preparations for skiing competitions, sports holidays, various school competitions, as well as the preparation of young people for passing ski standards were carried out by teachers of Kremenets Lyceum Julian Kozlowski and Galina Falkowska [3].

Later on the skiing movement gained a wide scope in Krements district. It was popular with young people and other segments of the population. Of course, it required extensive work and planning. The State Defense Section and Physical Education Section tried to create all the possibilities to develop ski sports and found reasons and conditions to make Kremenets the ski capital of Volyn. 
On January 15, 1933 in Kremenets, near Hnyle lake the first ski jumping track was opened thanks to the initiative of Professors Kozlowski and Berger (who conceived the idea of ski jumping construction in Volyn). It was built on the land donated by the Lyceum, which provided relevant territory and building material, as well as with the help of Physical Education and Military Training County Committee finencing, without any government assistance [13].

Skiing became one of the favourite and most popular sports, that is why Volyn Regional Union of Skiers was created here, in Kremenets. Professor Julian Kozlowski played a major role in this matter.

On December 16-17, 1933, the skiing committee of the Association of Public Organizations organized a conference, where all Volyn sports clubs and sports centers participated successfully. There were discussed questions connected with the state of skiing in Krements, including the work in sports centers, a ski equipment exhibition was organized there too. In the end, there was made an important decision: to create Volyn District Union of skiers, headed by Professor Julian Kozlowski. After the conference he held a demonstration session in ski gymnastics [17].

And on November 24, 1935 in Kremenets the representatives of local authority and delegates of Volyn sports clubs took part in a general conference which was dedicated to the development of skiing in Volyn. The participants of the conference listened to the full reports read by professors Kozlowski and Gronowski, as well as the report given by the management of Volyn District Union of Skiers. At this conference Julian Kozlowski, professor of Kremenets Lyceum, was elected a chairman of Volyn Regional Union of Skiers [7].

Previously in Kremenets there was a plan to create a public swimming pool but the plan was not implemented and remained only the plan. Julian Kozlowski initiated this issue at the meeting of united public organizations and this task became a priority for the union. As a result, a swimming pool with appropriate technical requirements for all comers was opened on the River Ikva in Mlynivtsi, which is 5 kilometers from Kremenets, on June 14, 1933. The size of swimming pool was 50x60 meters, its depth was 1.5-4 meters. The swimming pool was equipped with wooden starting places and 5 lanes, their length was $50 \mathrm{~m}$, as well as a jumping tower with three levels $(1 \mathrm{~m}$, $3 \mathrm{~m}, 5 \mathrm{~m}$ ). To enter the water some platforms and steps were built there. Everyone could use a sandy beach which had several changing rooms. In addition people were provided with medical services.

After the grand opening of the swimming pool there were swimming competitions of the following kinds: $50 \mathrm{~m}$ men's and women's classic swimming, $100 \mathrm{~m}$ men's freestyle and tower jumping. It was Professor Kozlowski who prepared the pool for the opening and organized that competition. The organizing part of the competition and the preparations for the opening of the pool were done by Professor Julian Kozlowski.

The importance of the pool for Kremenets was very great not only with regard to the development of sports, but also in terms of revitalizing the cultural life of the city [18].

Also, Julian Kozlowski directed the organization of competitions initiated by Maritime and Colonial League, which was established in Kremenets in April 1934. The program of these competitions included: swimming, kayaking, diving, jumping from tower to water.

The Training and Military Training Committees traditionally organized physical education holidays which lasted for a week every year in Kremenets. This event summed up everything that had been done over the year advertising physical culture and sports successfully. Julian Kozlowski organized these holidays and he was the judge of these competitions [3].

He was also an active organizer and judge of intercollegiate athletics, volleyball, basketball, and swimming competitions [2].

In 1932 cooperation with the gymnasium named after Sulkowska, initiated by Director Tadeusz Lopuszanski, teachers Oscar Zawrotski (Rydzyna) and Professor Julian Kozlowski (Kremenets), played an important role in the sports life of Kremenets Lyceum. Its purpose was to raise the level of physical culture and sports, to bring young people closer to the two institutions, to bring up noble behavior during competitions. Annual competitions were held alternately in Rydzyn and Kremenets. The team consisted of 15 participants. But only those students who studied well 
could take part in these competitions. These were team competitions and it was very important for students. It was required that each participant should have a State Sports Honour .

The program of compititions included: athletics triathlon, pentathlon, relay racing, basketball, handball, tennis, small-caliber shooting and shooting from military firearms. In total, there were six such competitions [20].

On May 2, 1936, Kremenets Lyceum Inter-School Sports Club was opened during the holiday, which was annually celebrated in Kremenets Lyceum, the guardian of the club became Professor Kozlowski [19].

Julian Kozlowski often personally participated in sports competitions. Thus, in January 1934 the ski jumping competitions, in which famous sportsmen of Lviv and Kremenets clubs participated, took place in Kremenets. In these competitions Kozlowski took the second place, he jumped $24 \mathrm{~m}$, it was the second result, the first place went to champion of Poland Joseph Lankosz, who jumped 29 $\mathrm{m}[12]$.

Professor Kozlowsky was a great fan and promoter of motorsport. He won the $30 \mathrm{~km}$ race, competing on a motorcycle «Norton», during the competition organized by the Motorcycle Section of the Association of Public Organizations in Kremenets on October 16, 1937. Motorcycle figure skating competitions took place in Kremenets on October 23, 1937, where he took the second place [1].

Julian Kozlowski became one of the initiators of the development of glider sports in Kremenets region, he created Volyn Glider School, located near mountain Sokolyna in Kulykiv village near Kremenets in June 1933 [16].

During the Second World War, Julian Kozlowski volunteered for the front. Beihg an extremely brave man, a great patriot of his country, he died heroically near Vilaniv village on the 18 of August in 1944. He left his wife Felicia and daughter Jadwiga, who was a Kremenets Lyceum pupil.

Julian Kozlowski was awarded the Cross of Merit in 1933, the Medal for the War of 19181920, the Medal for the Second World War. He got the Order of Virtutti Militari of 5th degree for fighting an enemy in the ranks of the Krajova army [14].

Conclusions. Professor Julian Kozlowski made a great contribution to the development of physical culture and sports not only in the Kremenets Lyceum, in Krements region, but also in Volyn.

It was difficult to overestimate the great merit of professor Kozlowski. He initiated the construction of springboard for ski jumping in the area of Hnyle Lake and the pool on the river Ikva in Mlynivtsi. He founded the Union of Volyn Regional Skiers in Kremenets, introduced the mass tests for the state ski sports honors. He was one of the initiators who created Volyn Glider School.

During his work at Kremenets Lyceum, Julian Kozlowski strengthened its material and sports base.

He also did a lot of work to organize different levels of sports events and celebrations. He proved himself to be a competent leader and organizer being elected to various positions in Kremenets Sports Club, Volyn Regional Skiers' Union, and the State Defense and Physical Education Section of the Association of Public Organizations.

Professor Julian Kozlowski also wrote o lot of newspaper and magazine articles not only about sports competitions, events, but also about the education of athletes according to the certain ethical and sports norms of behavior, trying to raise the moral level of athletes. He believed that all athletes should adhere to the most important principles: losers and winners cannot be in any sport, there are no best or worst competitors, better-trained athletes should help weaker ones so that they could achieve better results.

Also, being the great patriot of his country, Julian Kozlowski fought for Poland's independence and liberty without paying attention to his life. 


\section{Literature:}

1. Fuchs J. Motorcycle competition in Kremenets. Monthly magazine «Life in Kremenets»». - 1937. - № 20. - P. 399. Lutsk State Archive 352Z99.

2. Gronowski L. Ski course Z.O.S. Monthly magazine «Life in Kremenets», Kremenets High School, District Department in Krzemenets, Union of Social Organizations in Kremenets District, printing house of W. Cwik. - 1932. - № 2. - P.32.

3. Kozlowski J. Report on inter-school sports holiday. Life of Kremenets High School. № 6. - May 1931 - P.7.

4. Kozlowski J. Skiing and its development in Kremenets. Monthly magazine «Life in Kremenets» Kremenets High School, District Department in Kremenets, Union of Social Organizations in Kremenets District, printing house of W. Cwik. №1 - 1932. - 23 p.

5. Kozlowski J. Ski Badge for efficiency. Monthly magazine «Life in Kremenets » Kremenets High School, District Department in Kremenets, Union of Social Organizations in Kremenets District, printing house of W. Cwik. - 1932. - № 12 - P. 35-37.

6. Kozlowski J. About medical and educational care in sport. Monthly magazine «Life in Kremenets». - 1934. - № 9. - P. 297-300.

7. Kozlowski J. All-Volyn Ski Conference. Monthly magazine «Life in Kremenets». 1935. - № 12. - P. 531-532.

8. Kozlowski J. Preparation for the ski season. Monthly magazine «Life in Kremenets» Kremenets High School, District Department in Kremenets, Union of Social Organizations in Kremenets District, printing house of W. Cwik - 1933. - №10. 409 p.

9. Kozlowski's biography SYC.ARCH. Kol 23. Underground Movement Study Trast (1939-1945): London. - P. 32.

10. Kremenets High School in 1920-1935. Collection of works. - Kremenets. - May 1935

11. Kwasnik E. Opening of the ski jump. Youth magazine of Kremenets Lyceum., Our expedition. Kremenets, printing by Br. Juzefowych. - 1932-1933. - P.5.

12. Levandovska O. Julian Kozlowski, professor of Kremenets Lyceum, was a prominent figure in the field of physical culture and sports development in Krements region during the interwar period. Concept of physical education and sport development in Ukraine. Collection of Scientific Papers, Edition VI, Part II. - Rivne. - 2009. - P. 5-13.

13. Our dugout. Part II, 1932-1933. 5 p. Conception of Kremenets High School. Life of Kremenets High School, Published by Kremenets High School, № 6. - May 1931. - 7 p.

14. Private archive of Levandovski family. Letter from Anna Koscia-Czarnocka to O. Levandovska with memoirs and materials of Polish Emigration Archive in London (Biography of Julian Kozlowski, Underground Polish Studies, London, typescript), London. - 2009.

15. Reorganization of Kremenets Sports Club. Monthly magazine «Life in Kremenets». 1938. - № 23-24. - 551 p.

16. Secretly from Kremenets. Dialogue of two cultures. Annual journal VII, Book II, Lublin. - 2013. - p. 155-175.

17. Ski conference. Monthly magazine «Life in Kremenets» Kremenets High School, District Department in Kremenets, Union of Social Organizations in Kremenets District, printing house of W. Cwik № 12. - 1933. - $472 \mathrm{p}$.

18. Stakhurski R. Opening of the swimming pool. Monthly magazine «Life in Kremenets» Kremenets High School, District Department in Kremenets, Union of Social Organizations in Kremenets District, printing house of W. Cwik - 1933. - № 6. - 269 p.

19. Stakhurski R. Opening of the Interschool Sports Club. Kremenets High School on the 2nd and 3rd May in Kremenets. Monthly magazine «Life in Kremenets». - 1936. - № 5. - pp. 210-212. 
20. Swierzynski J. Interschool competition Rydzyna-Kremenets. Rydzyna school, memories and grades. Sympozium Gimnazium / Lyceum named after J. Sulkowski in Rudzyna (1828-1939) progressive pedagogical thought. - Rydzyna. - 1978, 64 p.

21. Zhywek L. Influence of Krzemenets High School on the development of sport life in Kremenets in the interwar period. Dialogue of two cultures, Almanac VI, Part II, Lublin. - 2011. - P. 257-276. 